https://doi.org/10.18485/iipe_response2covid19.2021.ch15

\title{
THE POOR DONOR AND THE RICH RECIPIENT. FOREIGN AID AND DONORS' COMPETITION IN THE COVID-19 ERA
}

\begin{abstract}
Igor Pellicciari ${ }^{1}$
Abstract: Much of the international relations during the COVID-19 period concerned inter-state health aid, ranging from emergency supplies of medical supplies during the virus outbreak phase to the distribution of vaccines during the following phase of immunization campaigns. These were bilateral assistance interventions, with the multilateral dimension effectively absent and unable to act. Motivated by geopolitical logic, they were expressions of the foreign policies of the states involved, re-proposing the pattern of the War of Aid as seen in the main international crises of recent years (from Ukraine to Syria, from Kosovo to Afghanistan). The emblematic case of the emergency phase was that of Italy, the first accessible world pandemic scenario. Alongside a classic competition between donors, won by Russia, there were a series of unprecedented cases, such as that of a Rich Beneficiary, a G7 country with its own strong autonomous spending capacity - assisted by Poor Donors, bearers of symbolic aid. The following phase has seen the clash between a Western Economic Vaccine model, driven by more private and commercial logic, and an Eastern geopolitical vaccine, of public origin and controlled entirely by the States that have used it as an instrument for their foreign policies. The worldwide visible case of the supply of Sputnik V to the micro-Republic of San Marino, the first sovereign country in the world to become COVID-free, has shown that the main importance of the vaccine was in its being an instrument of foreign policy and geopolitical impact.
\end{abstract}

Keywords: foreign aid, foreign policy, COVID-19, vaccine, Russia, Italy, San Marino.

Writing in 2021 about any topic, especially if linked to the international dimension, requires an attempt to understand how much it has been affected by COVID-19. Paradoxically, this has led us to focus more on the "after" than on the

\footnotetext{
${ }^{1}$ Full Professor, University of Urbino, Italy, igor.pellicciari@uniurb.it.
} 
"while", to investigate an uncertain future more rather than a certain present, and to outline some already visible scenarios, defined by trends consolidated since the first months of this emergency.

Among these, one of the main trends concerned the powerful rise of State Aid as the main vector of international relations, particularly in the very first months of the pandemic. Then it opened the door, in the following phases of the pandemic, to the phenomenon of the geopolitical use of the vaccine.

The following article explores these Aid relationships according to a division into three phases that marked the pandemic progress in the first 18 months since its appearance. The first phase of the virus outbreak (February to May 2020), the second phase of stabilization in Europe and surge in the rest of the world (June to October 2020), and the third phase of recurring waves of infection (attenuated around June 2021).

\section{PANDEMIC PHASE ONE: THE ECLIPSE OF THE MULTILATERAL}

The main characteristics of the initial phase were the fact that the absolute protagonists of this Aid diplomacy were the traditional Nation-States, and that basic medical-sanitary supplies were at the centre of assistance. The states were the only ones to bring to life, on a bilateral basis, an international scene that had suddenly frozen, aggravated by the initial lack of information on the new virus and by the unpredictability of the duration of the pandemic itself. These emergency medical devices (masks, gloves, sanitizing products, etc.) became in the first quarter of 2020 the main object of Aid, real or promised, incoming or outgoing, between countries.

Although COVID-19 highlighted problems of internal cohesion within sovereign states themselves, when imposing restrictive measures on regional and local authorities to contain the virus, what has caused a stir during this phase was the absence of a multilateral dimension.

None of the main international multilateral organizations seemed to be spared by this crisis.

Politically weakened by the unilateral decision taken by the member states to cancel Schengen, the sacred symbol of European integration, the EU has lost months discussing how to organize aid, moreover directed internally to its own member states. In doing so, emergency interventions directed at the bordering areas that were traditional destinations of the EU's massive aid assistance - making Brussels one of the main donors - have taken a back seat. NATO, for its part, has done even less and has not gone beyond simple statements of political 
condemnation of Russian and Chinese Aid to Italy. Furthermore, it was unable to organize any of its own initiatives or to solve "logistical" tensions among allies, such as Turkey's blockade of protective masks destined for Italy.

Perhaps the most plastic demonstration of the crisis of the multilateral dimension during COVID-19 is the passivity of the United Nations. After having invested considerable energy in an attempt to refocus on the theme of climate change, and also to survive as an organization and to avoid spending reviews applied to its excessive and expensive branches, the UN was particularly unprepared for the virus. The same fate befell the numerous UN agencies, with the sole brief exception of the WHO, which initially seemed to be sheltered from this crisis of the multilateral dimension.

Instead, after a series of delayed decisions with respect to the scenario (the official announcement of the pandemic emergency), or contradictory recommendations (regarding the usefulness of tests and masks), or stances on the genesis and management of the pandemic (openly praising Beijing), the respect for the organization gave way first to suspicion and then to open criticism with widespread sarcastic tones. Unable to secure its own political autonomy from its shareholder nation-states, ${ }^{2}$ the WHO has shown the limits of Organizations that have never become autonomous Institutions oriented towards the management rather than policy-making, incapable of imposing inconvenient technical truths on the political pressure of the moment.

\section{THE ITALIAN CASE: RICH RECIPIENT AND CATCH ALL DONORS}

The greatest changes in Aid recorded in the first phase of COVID-19 concerned Italy, not so much because of the policies implemented by Rome to fight the pandemic, but because this was the initial "accessible scenario" of the virus outside China. The most evident peculiarity with respect to the past was the sudden and unexpected emergence of a "Rich Recipient"; a country among the world's leading economies, with a consolidated democratic constitutional political system and its own significant spending capacity. Such a high level of development and stability, both political-institutional and economic-social, was unprecedented for a Recipient country. This has allowed Italy to act as an atypical Recipient. Not in transition and with a functioning political system, it has been able to maintain

\footnotetext{
${ }^{2}$ On state contributions to the WHO, see Daugirdas, K \& Burci, G.L.(2019). Financing the World Health Organization. What Lessons for Multilateralism? International Organizations Law Review,16, pp. 299-338.
} 
high levels of negotiating power to guide and monitor its territory with respect to Donors coming from outside. In addition, Rome found itself in the rare situation of a recipient that had, regardless of the Aid received, its own pre-existing and large financial resources, typical of a G7 country, to implement autonomous defensive actions against the virus.

These actions concerned the approach related to the procurement of protective devices (which, incidentally, often turned out to be of very poor quality) for about 4 billion Euros, entirely self-financed by the resources of the Rich Recipient. Donors had no say over these purchases. The sudden appearance of an unexpected scenario of such geopolitical interest has made many nation-states realize the potential for diplomatic reinforcement that an aid intervention in Italy would have brought, regardless of its size. Therefore, starting in March 2020, there has been an outpouring of various initiatives of emergency bilateral aid, directly emanating from the governments of Donor States. Among the incoming Donors, Russian, Chinese, and US aid moved simultaneously, although with a considerably different intensity, in a strictly separate mode and total autonomy, showing the main political philosophies underpinning their different approaches to aid. ${ }^{3}$

This was a revival, in a new context, of the "War of Aid" already observed in other recent contexts (above all, Ukraine and Syria) and which, in the global reshuffling of the cards and zones of influence at a global level, has increasingly seen the same Key Donors competing for the primacy of intervention towards the "new" recipient of the moment.

Geopolitical competition aside, Russian aid has been the most evident one in Italy during the first emergency phase. What aroused anxiety in the West was the military character of this aid delivery, managed entirely by the Russian Ministry of Defense (it is quite unique to see Russian soldiers operating in a NATO country). As part of the "From Russia with Love" campaign, Russia sent eight mobile brigades specializing in virology and bacteriological warfare to Italy, along with medical equipment and machinery for assisted ventilation and disinfection. In the competition among Donors in geopolitically important Italy, hypothesizing the objectives of the Kremlin's aid campaign has been of central importance in understanding its goals in politics, not just foreign policy.

Based on the available information, three different types of interest behind the Russian intervention in Italy can be identified: geopolitical, domestic political and strategic health intelligence. The geopolitical motive is the one in best

312 March 2020: Chinese material aid; 22 March 2020: Russian material aid; 10 April 2020: US financial aid. 
continuity with the idea of state aid in the Soviet sense, inspired by the Kremlin's foreign policy tradition of rewarding allies or more generally friendly countries, with whatever means of support at their disposal. Repeated almost mechanically by diplomats on top of the Russian governmental machine in the second decade of Putin's legacy, this approach considers the (geo) political objective as prevailing over economic costs, seen with resignation as a collateral price that is acceptable to achieve the goal. Well, Italy has long been consolidated as NATO and the EU's closest country to the Kremlin, regardless of the governments that have succeeded one another in Rome (Lilik, 2018); reason enough to continue to pay attention to it, even more so after its energy dependence on Moscow has increased due to the Libyan crisis.

The second reason for the Kremlin's intervention to the benefit of Italy was Russia's internal political situation, where one of the main changes during the Putin era has been the shifting of the political system from a legitimacy based on the availability of financial resources to a real popular consensus.

In just over three decades, in order to limit the weight and excessive power of the oligarchs and return to the primates politicae of state institutions, efforts have been made to develop a lower-middle class, largely coinciding with the enormous civil service and acting as the backbone of consensus in the country. This led to a new and unusual (in the Russian tradition) attention of the establishment to the views of this class, which in recent decades has developed a popular orientation of widespread attraction towards Italy. Perhaps because it is rigorously de-politicized, the penetration of Italian culture and commerce into Russia has established itself from the bottom up in all sectors of Russian society and the consumer economy, from clothing to services, from tourism to entertainment. Promoting towards Italy a campaign of aid and love (an unusual word for a military mission, generally identified by terms like friendship) was a popular move domestically, intended to strengthen the legitimacy of the Russian establishment.

The third reason at the root of Russian aid to Italy has been evocatively defined as strategic-sanitary intelligence and reveals why Moscow sent a military contingent rather than a civilian one..

As a country traditionally obsessed with the objective of defending from external attacks a territory too vast to be guarded, since the years of the Cold War, Russia has also developed among its possible crisis scenarios those resulting from a chemical-bacteriological attack linked to terrorist attacks.

Consequently, over the decades, considerable resources have been allocated to chemical-bacteriological research and channelled into the military sector, simply because in Russia, high-level technical innovation has always been first developed 
within the defence sector, even on topics that in the West are of civil competence. It is credible that the Russian intervention was aimed at collecting directly in the field information on bio-data regarding the progress of COVID-19 in Bergamo and Brescia, both to obtain valuable information on virus mutations in advance and to accelerate its own research work to develop a vaccine against COVID-19.

\section{THE POOR DONOR}

Another novelty of the Italian case, until then considered a textbook hypothesis, was the appearance of what could be called Poor Donors. In other words, new Bilateral Donors were coming from countries considered developing according to the common criteria established by the OECD (OECD, 2020). As protagonists of an unprecedented relationship of the type "Poor Donor-Rich Recipient" in Italy, they have enjoyed great international visibility even if their interventions have been very limited in size. ${ }^{4}$

In light of the existing geopolitical relations between the two countries, the most interesting case was that of aid from Albania, which for decades had been relegated to the role of Recipient of Aid, particularly from Rome.

Following the realist approach according to which the Donor dominates the relationship with the Recipient, ${ }^{5}$ it is legitimate to ask what pushed Albania to organize aid to Italy and what advantages it received in geopolitical terms. And, equally, why did Rome accept a limited aid campaign worth only 100,000 USD (!!?) and which consisted of a number of medical and nursing volunteers sent to Italy? Actually, with its symbolic intervention, Tirana has immediately capitalized on several important results that justify its effort to be a Donor, such as an international prestige and a return of sympathy collected in public opinion, not only Italian but also a strong surge in domestic popularity, due to the reversal of the narrative of the country-always-recipient that has historically characterized Albania, especially in relations with Italy.

\footnotetext{
${ }^{4}$ Albania, Cuba, Egypt, Pakistan, Turkey, Ukraine are recipients of Italian ODA who became donors to Italy in 2020. See Ricci Sargentini, M. \& Soave, I. (2020, April 16). Coronavirus, la mappa degli aiuti: ecco i Paesi che hanno sostenuto l'Italia. Corriere della Sera, retrieved from https://www.corriere.it/esteri/20_aprile_09/coronavirus-mappa-aiuti-ecco-paesiche-hanno-sostenuto-l-italia-12ffb40a-79ba-11ea-afb4-c5f49a569528.shtml. Accessed 30 August 2021.

${ }^{5}$ For more information, see: Morgenthau, H. (1962). A Political Theory of Foreign Aid. The American Political Science Review, 56(2), pp. 301-309; Baldwin, D. A. (1969). Foreign Aid, Intervention, and Influence. World Politics, 21(3), pp. 425-447.
} 
Among the medium-term results, there was Albania's legitimate expectation of receiving future privileged treatment from Rome on sensitive bilateral issues between the two countries, such as, for example, the regularization in Italy of a large Albanian community of recent arrival, as well as Rome's convinced support for Albanian membership to the EU, currently undergoing discussions of timing rather than means. Finally, with the foreseeable return after the pandemic emergency to the classic role of recipient of assistance from Italy, Tirana would certainly benefit from greater negotiating power with Rome on the conditions to receive future incoming Italian aid.

In the light of such Albanian intervention of maximum yield at minimum cost, it becomes even more interesting to look for Rome's realist motivation in accepting (rather than refusing) a small aid coming from a minor country. The motivation can be found in the Italian government's need to escape the pressure of the competition among American, Russian and Chinese aid, with explicit Western invitations to refuse Moscow's and Beijing's aid. In accepting aid from Tirana and other poor donors (such as Cuba, Tunisia, etc.), the centre of gravity of the internal discussion shifted from the insidious level of "which aid to choose" to the more easily manageable and de-politicized level of "any aid, even small, is welcome". Not to mention that Tirana's rhetorical statements on the importance of "not forgetting your friends in time of need" came at the appropriate moment for Rome, as the Recovery Fund was under negotiation in Brussels, and they appeared to be addressed in polemic to the countries led by the Netherlands, who promoted a more limited use of the European solidarity instrument.

The perfect timing of these messages for Italy, credible because they came from a third party, leads to the hypothesis that Rome itself advised Tirana to take the field, even if only with a symbolic intervention. This would help make sense of the Albanian aid intervention and how it has easily subverted the traditional belief that the Donor is always politically superior and more influential than the Recipient (Pellicciari, 2020).

\section{Pandemic Phase 2 and 3: Vaccine as Aid}

The Donors competition in the first phase soon led to the assumption that the confrontation would shift from emergency medical interventions towards the development of a COVID-19 vaccine.

This became a strategic weapon for those who had full control of it, similar to the impact on international relations, with due distinction, of the nuclear weapon after World War II. Although it has established itself as a primary resource aspired 
to everybody without exception, the vaccine has not had the same value everywhere as a geopolitical instrument of aid.

There has been a profound variation in intensity and efficacy of its use between Western countries (especially in the EU) and Eastern countries (especially Russia and China). With a clear predominance of the latter over the former. Between the two, there has been a profound difference in the morphology of the production and distribution chains of a "Western Economic Vaccine" and an "Eastern Geopolitical Vaccine". The main differences between the two have been generated by a clear dichotomy between the private-entrepreneurial approach of the former and the public-state approach of the latter, respectively (Pellicciari, 2021)

\begin{tabular}{|l|l|}
\hline Western Economic Vaccine & Eastern Geopolitical Vaccine \\
\hline Private (Companies) & Public (State) \\
\hline Original commercial purpose & Original geopolitical purpose \\
\hline Indirectpolitical control & Direct political control \\
\hline National target: economic recovery & National target: political consensus \\
\hline $\begin{array}{l}\text { Secondary international target } \\
\text { (e.g. Covax) }\end{array}$ & Primary international target (e.g. Aid) \\
\hline $\begin{array}{l}\text { Multilateral (European Union) } \\
\text { Protectionist unilateral (USA, UK) }\end{array}$ & Active bilateral \\
\hline
\end{tabular}

\section{The Eastern Geopolitical Vaccine}

The Eastern Geopolitical Vaccine (EGV) was born under a rigid state matrix that sealed its fate from research to distribution. It has been able to count on the support of national governments in states with predominant public economies and specialized know-how in the defence sector, inaccessible to the private sector.

The first geopolitical advantages of this genesis were both the availability of immediate and almost unlimited public resources for research, free from costbenefit considerations typical of the private market, and the possibility of enjoying unmediated political support and greater operational freedom. The Russians and Chinese have followed protocols (often military ones) that are much more 
streamlined than those of the West. At the same time, they were less bureaucratized and less transparent, not subject to the oversight of independent third-party authorities, a crucial aspect in the initial phase of research and testing. This is the emblematic case of the Sputnik $V$ vaccine, whose state imprint was already underlined by the "sacred" name chosen to baptize it, and whose discovery was experienced and presented by the Kremlin with the same satisfaction as when it achieved primacy in the space race during the Cold War.

The few experimental data released by the Russian health authorities - the main argument used at the time by sceptics of the efficacy of the discovery - now suggest that the initial phase of research and first elaboration of the vaccine started in the defence sectors, destined to remain secret by definition. Originally conditioned by the public sector, the EGV has been a monopoly of the State, which has been able to decide its use thanks to the direct political control of the related operational tactics, starting from the crucial definition of the vaccine distribution plans. At the domestic level, starting national campaigns for mass immunization earlier than the West was charged with a political significance of strengthening consensus towards the establishment to the point of placing this objective among the primary goals pursued by the EGV, not only Russian but also Chinese. However, it is at the international level that the EGV has fully expressed its foreign policy potential, which is determining if compared to the almost non-existent one of the Western Economic Vaccine.

The state matrix made it a flexible geopolitical tool, allowing Moscow and Beijing to move as Donors and decide to whom they would deliver it first on privileged terms. Following an established political tradition, the vaccine was conceived as an instrument of aid power politics to be directed to friendly and/or allied countries that formally requested it, exclusively through diplomatic channels. The choice of where to direct Sputnik $V$ beyond national borders was therefore a purely foreign policy decision taken at the government level, with the Russian Direct Investment Fund that entered the field only later to deal with technical aspects without being able to deviate from the strategic indications indicated upstream. The fact that the international target was more important than the domestic one was demonstrated by the strict separation between the rapid progress of the agreements for the export of Sputnik $V$ (in more than seventy countries) and the slow progress of the Russian national immunization campaign.

In light of this strong identification with foreign policy, the final important aspect of the EGV is its clear positioning within the bilateral relations of the Donor State at the expense of the multilateral dimension. Sputnik $V$ has been sent by Russia only to those countries that have formally requested it through institutional governmental and diplomatic channels. Neither parallel negotiation channels on 
a commercial basis nor private mediation, tolerated in the past in other fields such as energy, have been foreseen and tolerated.

\section{The Western Economic Vaccine}

The Western Economic Vaccine (WEV) has proceeded in the opposite manner to the Eastern one. It was inspired by commercial logic and conditioned by declared primary economic-social goals. The commercial logic was attributable to patent holders and those primarily responsible for its production, i.e., pharmaceutical companies of large dimensions. These were private entrepreneurial subjects driven by declared goals of profitability and, by definition, scarcely sensitive to a political rationale.

The economic and social goals have instead been emphasized by the same Western governments that were concerned about the health crisis and the widespread tensions resulting from prolonged anti-contagion measures, and who hailed the vaccine as the main way to reconcile economic recovery and public health. Surprising, particularly within the European Union, has been the lack of initial political debate on the appropriateness of such a strongly privatecommercial connotation of the vaccine, which did not take into account the European political tradition of keeping the essential community services public. This convinced placement in the private sector negatively affected government control over vaccine production as well as its possible future geopolitical use.

First, Western leadership could not take credit for the discovery of the vaccine, which excluded them from the effect of increasing domestic consensus and popularity, observed instead with the Eastern Geopolitical Vaccine. But the most obvious negative impact of the private, de-politicized status of the vaccine on Western countries lies in the failure of their respective foreign policies American, British, but also European - to develop health aid interventions. Without direct control over the production process and depending entirely on the supplies of Big Pharma, the Western institutional level has been entirely absorbed by negotiations, drafting and signing contracts to ensure the necessary doses for their domestic needs.

This has put into the foreground the target of national vaccination campaigns and extremely weakened, for lack of doses from pharmaceutical companies, international strategies of vaccine aid to third countries (see the weak multilateral campaign Covax), in line with the model of the EGV. Some countries, such as the United States, Great Britain, and Israel, however, have interpreted this orientation with a pragmatic unilateral policy of closed borders, which has allowed them to effectively manage (at least) their respective national vaccination campaigns. 
More complex and problematic at the domestic level has also been the approach of the European Union that confirmed the operational crisis already manifested during the first pandemic phase by playing the passive role of the negotiator tasked with purchasing doses to be redistributed to its member states. On this occasion, Brussels has again demonstrated slow reflexes in times of emergency, redundant administrative procedures, sometimes self-referential, and technical inability to negotiate first and then enforce the delivery of supplies agreed with Big Pharma. Initially funded by the public sector as Implementing Agencies in charge of carrying out research on the vaccine, the Pharmaceutical Companies became autonomous, not responding to the Donor's directives on where and how to direct the distribution of doses for immunization campaigns.

The ineffectiveness of the $\mathrm{EU}$ in redistributing the vaccine internally turned to an open political delegitimization when some member states began to move in bilateral autonomy, negotiating with producers, sometimes including Russian ones, without involving Brussels. Even more serious than the case of Germany and Austria independently purchasing millions of WEV doses was the case of Hungary and Slovakia, the first EU member states to unilaterally decide to adopt the EGV. This has created an obvious "Trojan horse" effect of Russian vaccine geopolitics in the EU and an embarrassing precedent for Brussels and the remaining member states, forced to justify the resistance to the entry of the EGV before their public opinions, which were largely in favor of it. The technical arguments used by EMA in this regard and the usual complex legal-bureaucratic procedures for authorizations only reinforced the impression in the public opinion that the EU's fears about the EGV were related to geopolitical considerations rather than public health ones.

\section{The lonely race of the Eastern Vaccine}

The acceptance of the EGV, even under strong popular pressure, represented a major obstacle for the EU countries, facing domestic and international problems. In the immediate future, this would have meant acknowledging the failure of the private-entrepreneurial model of the multilateral WEV to the advantage of the public model of the bilateral EGV and its expansive aid policies. This would not have passed without painful consequences for the already scarce legitimacy of the European institutions, undermined by their inability to impose a common policy on the main pandemic issues (from immigration to tourism to the very defence of Schengen). Moreover, since Sputnik V was not only Russian but also literally "of Russia", its formal use by the EU would have meant recognizing Moscow as a Donor. Since there have been no international precedents of recipients retaliating against 
their donors, the European sanctions policy towards the Kremlin would have been affected, with an inevitable easing of the harshest aspects.

While the EGV was besieging the EU (February-March 2021) and winked at Western public opinion, which was confused and frightened by a mainstream with too much information and too little reliable data, the real geopolitical game of aid was being played out in the countries near the EU. In the vast space that goes from Africa to Central-Western Asia, passing through the Balkans. Here, the deafening absence of a vaccine aid policy on the part of those who, prior to Covid19 , had been the main donors in the area (the EU and the United States), was strongly felt. Engrossed as they were in trying, at best, to immunize their own domestic population, they gave up acting in times of emergency in countries of interest, where they had been the absolute protagonists. The empty space left was promptly occupied by bilateral donors of the EGV, headed by Russia, free to think in purely diplomatic terms and capitalize on the results of foreign policy.

Specific cases have multiplied. Especially astounding were those of Serbia and Moldova, where the mass arrival of Russian and Chinese vaccines has redesigned areas of geopolitical influence to the advantage of Moscow and Beijing and to the detriment of Brussels and Washington. This temporary channel of entry into strategic beneficiaries, if prolonged over time, would have allowed the "new" Donors to institutionalize their presence in the next phase, with future aid programs more structured and diversified, destined to last (Tsygankov, 2016).

This is further proof that the WEV countries have played a defensive game in the international system vis-à-vis the expansive one pursued by the EGV countries. Moreover, in the absence of a real Western competitor in the game, at least until April 2021, technically it was not possible to talk about a war of aid, but rather a Russian-Chinese solo race. This scenario had a decisive impact on the quality of Donor-Recipient relations and laid the foundations for future developments if, as hypothesized by some virologists, the medium-long term has multiple viral mutations and recurrent pandemics in store.

The prospect of continuous and recurrent vaccination campaigns has made the issue of periodic supplies of doses a cross-cutting priority on the government agenda of all countries. The competitive advantage accrued by the Donors of the EGV has been the ability to rely on already stipulated agreements and already active distribution networks in Recipient countries, as well as decentralized pharmaceutical production centres set up to address the enormous demand for vaccines. However, there will likely be a parallel attempt to regain an active role in the vaccine competition among Western actors who have been on the sidelines so far (The White House, 2021, June 21). Going from a situation of shortage to one of excess availability of vaccines offered by multiple manufacturers, the United 
States has already hinted that having achieved the immunization of their country, they will focus on the problem of regaining the space lost so far.

The European Union, for its part, has relaunched its Coronavirus Global Response at the Global Health Summit held in May in Rome on the sidelines of the $\mathrm{G} 20$, relaunching a multilateral approach with which it aims to regain the role of coordinator of donors on a global scale, abruptly interrupted by the pandemic. This coordinated action of the EU and US has led them to announce upcoming foreign policies of vaccine aid aimed at limiting the influence of the EGV, discouraging its use in friendly and allied countries to the advantage of their own vaccines. Heralding the return of what will be a full-fledged War of Vaccine Aid.

\section{SAN MARINO: THE AID SIZE DOES NOT MATTER}

Among the most interesting cases of the vaccine aid phase is that of the Republic of San Marino (RSM), a thousand-year-old independent micro-nation, an enclave located in Italy, between the cities of Rimini and Pesaro. The reason for this sudden attention to a state little known to most was a governmental choice to combat COVID-19 which combined aspects of domestic, international, and health policy that have become an emblematic synthesis of the main political issues concerning vaccine aid.

Despite having signed an agreement in the field of health collaboration with Rome at the end of February 2021, the RSM found itself lacking any vaccine doses due to the recalled initial problems encountered by the EU in distributing vaccines to its member states, including Italy. As one of the most affected countries worldwide (throughout 2020, it held the world record for mortality rate due to the virus), the RSM did not hesitate to start vaccinating its population on February 25, 2021, with Sputnik V, becoming de facto COVID-free at the beginning of June 2021. In the middle of the European discussion on the problems of the WEV and the opportunity to open to the Russian and Chinese ones, the RSM case immediately attracted a wide international interest because of the massive resort to the EGV by a Western sovereign country.

Giving great visibility to the case was the fact that the episode concerned a micro-state "surrounded" by Italy, that is, the country that only a few months earlier had not hesitated to request bilateral Russian emergency aid and now was prevented by the European multilateral dimension from accessing Sputnik $V$ as well, as requested by its public opinion. Furthermore, the rapid results on the effectiveness of Sputnik $V$ in the RSM, as evidenced by the drastic drop in infections in the country as well as clinical studies conducted in collaboration with Italy, had made it clear to the general public that Europe's aversion to the Russian 
vaccine was political rather than health-related. In the space of a few months, the RSM case has become emblematic of the development of foreign policy through aid in the era of COVID-19, from the point of view of both the Donor and the Recipient, and of the dynamics of the relationship between the two actors.

On the Donor's side, it confirmed Moscow's approach of a) negotiating and b) implementing under the public aegis of the entire chain of intervention, without involving private intermediaries (Contractors). Treating the decision to give the vaccine as a foreign policy action, moreover, helped to understand the reasons for Macro-Russia's interest in Micro-San Marino, which was met with surprise in the West. Similarly to the one that two years earlier had accompanied the state visit to the RSM by the Russian Minister of Foreign Affairs, Sergei Lavrov.

In 2014, facing Western isolation due to the Ukrainian crisis, in the European diplomatic desert, Moscow welcomed the fact that the RSM, appealing to its neutrality, had not joined the EU in sanctions against the Kremlin. This gesture had a strong symbolic impact on the Russian domestic front, both institutional where a hyper-state culture leads to respect for sovereignty (macro or micro, regardless), and popular - where millions of Russian tourists passing through Rimini over the decades have come to know the RSM very well. The Donor's choice was to put into practice the recalled diplomatic rule of support to nonhostile countries by using the vaccine as a reward for a state that had been "openly non-hostile", giving visibility to the case both domestically and internationally. The relevant political framework was enough for Moscow to decide to help the RSM, regardless of the limited size of its territory and population.

On the contrary, they represented an advantage since they allowed vaccination of an entire state with few doses, at a time when Russia was facing a shortage of available vaccines because of its choice to anticipate the negotiation phase before the production of the doses had actually taken place.

Finally, an important common aspect of Macro-Rusia and Micro-San Marino has been the historically difficult "sovereignty-territorial extension" they have had, with Moscow facing the problem of being too big (to be defended) and the RSM of being too small (to see its sovereignty fully recognized). This specular and opposite issue has impacted the Russian-RSM bilateral relationship of vaccine aid, influencing the political use made of the episode, played on different levels, respectively on the internal one by the Recipient and the international one by the Donor. Once it obtained mass immunization, the RSM promptly promoted it as the main asset to relaunch its domestic tourism, the main industry of the country, under the banner of the message of the first COVID-free country in Europe. Then again, Russia's ambition to bolster its foreign policy with vaccine aid was summarized in the Interfax news agency's piece on February 19, 2021, which, 
even before a single dose had reached the micro-state, emphatically titled that "The Republic of San Marino is the 30th country in the world to get Sputnik V" (Interfax, 2021).

\section{CONCLUSION}

In light of the above, the main conclusions of this article are:

- In the pandemic period, much of international relations was animated by the aid of emergency medical supplies in the first months of the virus outbreak and then, in the following phases, by the supply of vaccines against COVID-19.

- The nation-states in the bilateral dimension were the key players in these aid initiatives, while the multilateral dimension showed a profound crisis of action and reaction.

- Aid has given rise to a repeat of the Wars of Aid seen in the major international crises of recent years, with key players competing with Donors to position themselves in the scenario of geopolitical interest.

- In the first phase of the emergency, there was a Donors' competition to assist Italy, won by Russia. The Italian scenario has also presented the unprecedented case of a Rich Beneficiary, a G7 country with its own strong autonomous spending capacity assisted by Poor Donors (such as Albania), bearers of mostly symbolic aid.

- The following phase of vaccine aid has seen the clash between a Western Economic Vaccine model driven by more private and commercial logic, and an Eastern geopolitical vaccine, of public origin and controlled entirely by States that have used it as an instrument for their foreign policies, gaining ground in the competition between Donors.

- The iconic case of the supply of Sputnik $\vee$ to the Republic of San Marino has shown that the main importance of the vaccine was in its being an instrument of foreign policy and geopolitical impact.

On a general level, it has also confirmed once more that in the post-bipolar world, the history of international relations is not complete without a reading of the Aid, both outgoing and incoming, of the State actors involved.

\section{REFERENCES}

Bakalova, E., Spanger, H. \& Neumann, J. M. (2013). Development Cooperation or Competition? Russia as a re-emerging donor. Frankfurt am Main, Peace Research Institute Frankfurt. 
Baldwin, D. A. (1969). Foreign Aid, Intervention and Influence. World Politics, 21(3), pp. 425-447.

Daugirdas, K. \&Burci, G. L. (2019). Financing the World Health Organization. What Lessons for Multilateralism? International Organizations Law Review, 16, pp. 299-338.

Interfax (2021, Feb.19). Сан-Мариностало 30-йстраной, зарегистрировавшей вакцину "Спутник V" [San Marino became 30th country to register "Sputnik V" vaccine], retrieved from https://www.interfax.ru/world/751748. Accessed 30 August 2021.

Larionova, M., Rakhmangulov, M. \& Berenson, M. P. (2016). Russia: A Re-emerging Donor. In: J. Gu et al. (eds), The BRICS in International Development (pp. 6392). London, Palgrave Macmillan.

Liik, K. (2018). Winning the normative war with Russia. An EU-Russia Power Audit. London, ECFR.

Morgenthau, H. (1962). A Political Theory of Foreign Aid. The American Political Science Review, 56 (2), pp. 301-309.

OECD. Development Assistance Committee, retrieved fromhttps://www.oecd.org/ dac/development-assistance-committee/, Accessed 30 August 2021.

OECD. (2020). 2020 DAC List of ODA Recipients, retrieved from https://www.oecd. org/dac/financing-sustainable-development/development-financestandards/DAC-List-of-ODA-Recipients-for-reporting-2020-flows.pdf, Accessed 30 August 2021.

Kricković, A., Pellicciari, I. (2021, March 15). From Greater Europe to Greater Eurasia. Status concerns and the evolution of Russia's approach to alignment and regional integration, Journal of Eurasian Studies, retrieved from https://journals.sagepub.com/doi/full/10.1177/1879366521998808 Accessed 03 September 2021.

Pellicciari, I. (2020, April 5). Da Beneficiario a Donatore. La mossa di Edi Rama [From Beneficiary to Donor. The move of Edi Rama], Formiche, retrieved from https://formiche.net/2020/04/beneficiario-donatore-mossa-edi-ramapellicciari/ Accessed 04 September 2021.

Pellicciari, I. (2021). Nella partita dei vaccini l'Italia è in fuorigioco [In the vaccine game Italy is offside]. Limes Rivista Italiana di Geopolitica, No. 3, pp.77-88.

Ricci Sargentini, M. \& Soave, I. (2020, April 16). Coronavirus, la mappa degli aiuti: ecco i Paesi che hanno sostenuto l'Italia [Coronavirus, the aid map: here are the countries thathavesupporteditaly]. Corriere della Sera. retrieved from: https://www.corriere.it/esteri/20_aprile_09/coronavirus-mappa-aiuti-ecco- 
paesi-che-hanno-sostenuto-I-italia- 12ffb40a-79ba-11ea-afb4-c5f49a5695 28.shtml. Accessed 30 August 2021.

The White House. (2021, June21). FACT SHEET: Biden-Harris Administration Announces Allocation Plan for 55 Million Doses to be Shared Globally, retrieved from https://www.whitehouse.gov/briefing-room/statements-releases/2021/ 06/21/fact-sheet-biden-harris-administration-announces-allocation-plan-for55-million-doses-to-be-shared-globally/, Accessed 30 August 2021.

Tsygankov, A. (2016). Russia's Foreign Policy: Change and Continuity in National Identity, New York, Rowman \& Littlefield. 